Food, Dairy and Home Economic Research

http:/www.journals.zu.edu.eg/journalDisplay.aspx?Journalld=1\&queryType=Master

\title{
UTILIZATION OF YOUNG GREEN BARLEY AS A POTENTIAL SOURCE OF SOME NUTRITION SUBSTANCES
}

\author{
El-Shahat G. El-Dreny ${ }^{*}$ and G.S. El-Hadidy \\ Food Technol. Res. Inst., Agric. Res. Cent., Giza, Egypt
}

\section{Received: 15/04/2018 ; Accepted: 06/05/2018}

\begin{abstract}
Young green barley powder is one the best functional food of providing nutrition and eliminating toxin from cells in human beings, however its functional ingredients have played an important role as health benefit. Young green barley powder and wheat flour (72\% extraction) were analyzed for their proximate chemical composition, mineral elements and amino acids contents to evaluate their importance in human nutrition. The results showed that young green barley powder and wheat flour (72\% extraction) contains appreciable amount of essential nutrients whereas the ether extract content, crude protein, ash, crude fiber and carbohydrates were $3.23 \%, 21.15 \%, 9.37 \%$, $17.53 \%$ and $48.72 \%$ as well as $1.40,11.69,0.60,0.65$ and $85.66 \%$ (on dry weight basis), respectively. Also young green barley powder had high contains of macro mineral elements i.e. $\mathrm{Ca}, \mathrm{K}, \mathrm{P}, \mathrm{Mg}$ and $\mathrm{Na}$, high concentration of micro minerals' i.e. Fe and $\mathrm{Zn}$, besides amino acids such as arginine, lysine, histidine, phenylalanine, leucine, valine, alanine, glycine, glutamic acid, serine, threonine and aspartic acid. Five levels of young green barley powder $(2,4,6,8$ and 10\%) were used to replace wheat flour $(72 \%)$ in order to produce shamy bread. The obtained results showed that, as the level of substitution increase, all components increased except total carbohydrates. In addition, four levels of young green barley juice $(10,20,30$ and $40 \%)$ were used to replace cantaloupe juice. It can be concluded that consumption of young green barley in shamy bread or cantaloupe juice in different combinations could provide a reasonable daily recommended amount of essential nutrients for maintenance of healthy life and normal body functioning.
\end{abstract}

Key words: Young green barley, shamy bread, cantaloupe juice.

\section{INTRODUCTION}

Functional drinks are the fastest increasing division in the functional food group. In Thailand, functional beverage market increased from 1.8 billion in 2009 to 6.6 billion in 2014 . The consumer concern in natural functional drinks, with, senility, energy supplying, relaxing or beauty enhancing effects is increasing. To avert intake of chemical substances, natural substances from plant, which are than excelled animal sources, have been increasingly used as functional vegetarian components in drinks (Gruenwald, 2009).

Barley (Hordeum vulgare L.) is the fourth most significant cereal crop in the world and the highest dietary fiber content, its malt for functional food is not only the world's largest materials for beer, but also often used one of 300 species Chinese herbal medicine. The systematic consumption of whole grain barley and its hydroalcoholic extract reduce the risk of chronic diseases (cancer, diabetes, obesity and cardiovascular disease), depend on phytochemicals contain folate, flavonoids, phenolic acids, phytosterols, lignans, tocols and beta-glucan (Minaiyan et al., 2014). Barley with prophylactic cardiovascular and inflammatory diseases have exhibited activities contra all human platelet agonists stoped both lipoxygenase and cyclooxygenase pathways of arachidonic acid metabolism, which high the GSH-Pxactivities and superoxide dismutase SOD (Gul et al., 2014).

Corresponding author: Tel. : +201004238658

E-mail address: Dr.Elshahatgomaa12018@gmail.com 
Young green barley plants has young green leaves and stem of vegetative growth stage from seedling at 10 days after sprouting (barley sprout) to elongation stage (barley green) for nutritional peak before start reproductive cycle of barley (Park et al., 2015). Young green barley powder is not only utilized as a common green-coloured drink (Ikeguchi et al., 2014), but also is used in inhibition chronic diseases, particularly anti-diabetes, circulatory disorders, reducing cholesterol, reducing obesity, anticancer, anti-arthritis, anti-inflammation and antioxidant (Lahouar et al., 2015). Light can be quicken degradation and bioactive formation of cytokinins in young barley green leaves, which cytokinin oxidase / dehydrogenase activity positively associated with senescence (Schlüter et al., 2011). The amino acid and vitamin $C$ content in hydroponic young green barley powder are higher than that of organic soil (Meng et al., 2017). Spray-dried barley grass powder with good solubility and small size, revealed consist of the flavonoids and chlorophyll and SOD enzyme activity being $68.1 \%, 56.7 \%, 47.9 \%$ of vacuum freeze-dried powder with high nutrition and good colour, respectively (Gao et al., 2015). Although, young green barley powder has played an important role of human health, but coevolution and functional components as well as major mechanism in therapeutic role between preventive chronic diseases and young barley grass for functional foods of human being.

Young green barley powder consist of significant quantities of $\mathrm{Zn}, \mathrm{Fe}, \mathrm{Ca}, \mathrm{Mg}, \mathrm{K}, \beta$ carotene, folic acid, chlorophyll, vitamin $\mathrm{C}$, vitamin B12 and pantothenic acid (Lahouar et al., 2015). Young green barley powder contains 11 times $\mathrm{Ca}$ than that of cow's milk, and 4 times thiamine in whole wheat flour, 30 times thiamine, 7 times, vitamin $\mathrm{C}$ in oranges and 6.5 times carotene and 5 times Fe consist of spinach (Hagiwara et al., 2001), 2 times protein in barley grains (Yang et al., 2016), its total flavonoids and alkaloids are 2.1 times, 10.7 times of brown rice (Zeng et al., 2017).

Flavonoids in young green barley increased from 273.1 to $515.3 \mathrm{mg} / 100 \mathrm{~g}$ between 13 to 56 days after sprouting, however lutonarin (isoorientin-7-O-glucoside) has stronger radical scavenging activity than saponarin (isovitexin-7-
O-glucoside), its antioxidant ability is improved with growth time, which appear high total polyphenol $44.37-55.07 \mathrm{mg} / 100 \mathrm{~g}$. Total flavonoids extraction in barley grass is $94.66 \mathrm{mg} / 100 \mathrm{~g}$ (Zhang et al., 2013). There are 37 flavonoids and a hydroxyl cinnamates in young green barley include saponarin lutonarin, isoorientin, isoscoparine, O-glycosyl-C- glycosyl flavones, C-glycosyl flavones, O-diglycosyl-flavones, isoscoparin-7-O-glucoside derivatives and -7-O[6-acyl]-glc-4'-glucoside of isovitexin (Ferreres et al., 2008). The major flavonoid from extract are isovitexin-7-O-glucoside $(54.17 \%)$ and isoorientin-7-O-glueoside (33.36\%) (Gao et al., 2017). The major flavonoid antioxidants in young green barley are the flavone-C-glycosides, saponarin and lutonarin (Markham and Mitchell, 2003). Lutonarin and saponarin account for 71$75 \%$ of ten phenolics for young green barley contains $24.0 \mathrm{mg} / 100 \mathrm{~g}$ lutonarin and $14.0 \mathrm{mg} /$ $100 \mathrm{~g}$ saponarin (Jin et al., 2016). Syrian young green barley contains the derivatives of flavonols, quercetin and isorhamnetin, but flavonoids with glycosylation and acylation as well as hydroxycinnamates glycosides, esters and amides in methanolic extracts are different regions of the world (Piasecka et al., 2015).

Young green barley contained high mineral contents, principally sulphur, calcium, iron and potassium, its $\mathrm{Ca}$ was $33.2 \mathrm{mg}$ times, $\mathrm{K}$ is 14.3 $\mathrm{mg}$ times, Fe $13.4 \mathrm{mg}$ times, sulphur $3.3 \mathrm{mg}$ times of brown rice (Zeng et al., 2009). Young green barley contains 20 essential and nonessential amino acids with energy production, cell building and regeneration, especially eight essential amino acids (Lahouar et al., 2015).

Young green barley is advanced as a source of antioxidants, the most important being vitamin E, carotenoids, catalase (CAT), O-glycosyl isovitexin, superoxide dismutase (SOD) and vitamin C. (Janda et al., 2003; Lee et al., 2003).

Young green barley contents of vitamin C, total polyphenols, ferulic acid, mono saccharides and amino acids indicated that it's valuable plant components (Paulı'c'kova' et al., 2007).

The aim of this investigation is to evaluate the components of young green barley powder for chemical composition, minerals and amino acid contents and to evaluate the utilization of barley grass powder to produce shamy bread and cantaloupe juice in different combinations. 


\section{MATERIALS AND METHODS}

\section{Materials}

\section{Barley seed (Hordeum vulgare L.)}

Barley seeds Giza 129 cultivar was obtained from Barley Research Department, Agriculture Research Center, Kafr El-Sheikh, Egypt.

\section{Yung green grass barley preparation}

Seeds were washed and soaked in tap water for $24 \mathrm{hr}$. Floating seeds were discharged. Soaked seeds were then covered by wet cheesecloth for 12-48 hr., to let them sprout. Sprouts were placed on the to plastic pots and were covered by wet cheesecloth for 3 days. Then after, they were watered twice a day. Grasses of barley were harvested after 7 days when the seedlings reached $9-11 \mathrm{~cm}$ in height. Young green barley were subsequently ground to $2 \mathrm{~mm}$ mesh size sieve to form a fine and uniform powder for use.

\section{Chemical analyses}

Moisture, protein, ether extract, ash and crude fibers were determined according to the methods of the (AOAC, 2000). While total carbohydrates were estimated by subtracting the difference from initial weight of the sample as follow:

Carbohydrates $(\%)=100$ - [crude protein $(\%)+$ crude fat $(\%)+$ ash $(\%)+$ crude fibers $(\%)]$.

\section{Determination of mineral contents}

Mineral contents were determined according to the methods described in the (AOAC, 2000) using atomic absorption spectrophotometer. Total phosphorus content was determined coloraimetrically using the method of (Tausky and Shorr, 1953).

\section{Determination of amino acids}

Amino acids content of young green barley leaves powder were analyzed in National Research Center, Giza, Egypt, as follows:

Samples were subjected to acid hydrolysis using $6 \mathrm{~N}$ HCL. The hydrolyzate was recovered by removing the acid by evaporation in a rotary evaporator. The resulted amino acids were analyzed using amino acid analyzer (LC 3000 amino acid analyzer, High performance system, a product of LC biochrom Eppdrop, Germany). Flow rate $0.2 \mathrm{ml} / \mathrm{min}$, pressure of buffer form 0 to 2 bars, pressure of reagent to $0-150$ bar and reaction temperature $123{ }^{\circ} \mathrm{C}$. Amino acids were analyzed according to (AOAC, 2000).

\section{Chemical score of amino acid}

Chemical score of essential amino acids were calculated using the equation of $\mathbf{F A O /}$ WHO/UNU (1985) as follows:

Chemical score $=$

$\frac{\text { Essential amino acid } / 100 \mathrm{~g} \text { protein in sample }}{\text { Essential amino acid/100 g protein in FAO/WHO/UNU }} \times 100$

The amino acid that shows the lowest per cent value is called limiting amino acid, was the ratio obtained is the score.

\section{Computed protein efficiency ratio (C-PER)}

C-PER was calculated as given by Alsmeyer et al. (1974) using the equation:

C-PER $=1.815+0.435$ (methionine) +0.780 (leucine) +0.211 (histadine) - 0.944(tyrosine) .

\section{Computed Biological value}

Biological value (BV) was calculated as described by Farag et al. (1996) according the following equation:

Computed Biological Value (BV)=49.9+ 10.53 C-PER

Where:

C-PER = computed protein efficiency ratio.

\section{Technological Methods}

\section{Blends}

Young green barley powder was replaced at different ratios $(2,4,6,8$ and $10 \%)$ to wheat flour ( $72 \%$ extraction) to produce shamy bread as illustrate in Table 1.

\section{Baking techniques}

Shamy bread was prepared according to the method described by Ibrahim (1992). The basic bread making formula was as follow: $100 \%$ wheat flour ( $72 \%$ extraction) and/or wheat flour blends, $1 \%$ fresh baker compressed yeast, $1 \%$ salt and water as required for optimum consistency. 
Table 1. Blends young green barley powder with wheat flour (72\% extraction)

\begin{tabular}{ll}
\hline Treatment & Blend \\
\hline $\mathbf{1 ( C o n t r o l )}$ & $100 \%$ Wheat flour (72\% extraction) \\
$\mathbf{2}$ & $2 \%$ young green barley powder $+98 \%$ wheat flour (72\% extraction) \\
$\mathbf{3}$ & $4 \%$ young green barley powder $+96 \%$ wheat flour (72\% extraction) \\
$\mathbf{4}$ & $6 \%$ young green barley powder $+94 \%$ wheat flour (72\% extraction) \\
$\mathbf{5}$ & $8 \%$ young green barley powder $+92 \%$ wheat flour (72\% extraction) \\
$\mathbf{6}$ & $10 \%$ young green barley powder $+90 \%$ wheat flour (72\% extraction) \\
\hline
\end{tabular}

\section{Sensory evaluation of shamy bread}

Sensory evaluation of shamy bread was performed by 10 trained panelists as described by El-Farra et al. (1982) for general appearance (20), separation of layers (20), roundness (15), and distribution of crumb (15), crust colour (10), taste (10) and odour (10).

\section{Fortification of cantaloupe juice with barley drink}

$500 \mathrm{~g}$ from young green barley leaves were blended first using Moulinex machine. Blended leaves were transferred to 1 liter flask, water was added to complete the total volume to be $500 \mathrm{ml}$, and the content of the flask was mixed for 15 minutes and filtered. The obtained juice was used for fortification of cantaloupe juice with 10, 20, 30 and $40 \%$.

Sensory evaluation of cantaloupe juice with barley grass juice drink

Sensory attributes (colour, taste, odour, consistency, palatability, and overall acceptability) of cantaloupe juice with barley grass juice drink were evaluated directly after preparation by more than ten panelists (chosen by random) in the Food Technol. Res. Inst. according to the method of Lindley et al. (1993).

\section{RESULTS AND DISCUSSION}

\section{Chemical Composition of Young Green Barley Powder}

The chemical composition of young green barley leaves was determined. Results in Table 2 revealed that young green barley leaves can be considered as good source of crude protein, crude fiber and ash.
In addition it can be noticed that, ether extract $(3.23 \%)$, crude protein $(21.15 \%)$, ash $(9.37 \%)$, crude fiber $(17.53 \%)$ and total carbohydrate (48.72\%) are contents of young green barley leaves powder. The present results are in agreement with those of Foda and Mohamed (2007) who reported that, young green barley leaves powder contained, $9.6 \%$ moisture, $23.69 \%$ crude protein, $2.75 \%$ ether extract, $11.59 \%$ ash, $16.59 \%$ crude fiber and $37.74 \%$ total carbohydrate. Also, Table 2 cleared the chemical composition of wheat flour (72\% extraction), $11.69 \%$ for protein, $0.60 \%$ for ash, $1.40 \%$ for ether extract, $0.65 \%$ for crude fiber $85.66 \%$ for total carbohydrates. These results are in agreement with Khorshid $\boldsymbol{e t}$ al. (2011).

Mineral contents of young green barley powder and wheat flour (72\% extraction)

Results in Table 3 show that young green barley powder was rich in minerals $(\mathrm{K}, \mathrm{Ca}, \mathrm{P}$, $\mathrm{Na}$ and $\mathrm{Fe}$ ) except $(\mathrm{Mg})$ was poor compared with wheat flour (72\% extraction). These results are in agreement with the finding of Foda (2012) who reported that young green barley powder contained $(114 \mathrm{mg} / 100 \mathrm{~g} \mathrm{Na}),(3059 \mathrm{mg} /$ $100 \mathrm{~g} \mathrm{~K})$, (995 mg/100g Ca), (506 mg/100g P), $(15 \mathrm{mg} / 100 \mathrm{~g} \mathrm{Fe}),(16 \mathrm{mg} / 100 \mathrm{~g} \mathrm{Zn}),(17 \mathrm{mg} /$ $100 \mathrm{~g} \mathrm{Cu})$ and $(13 \mathrm{mg} / 100 \mathrm{~g} \mathrm{Mg})$. On the other hand, wheat flour ( $72 \%$ extraction) contained iron, zinc, manganese, magnesium, calcium, sodium, potassium and phosphors having 1.70, $4.2,0.80,105.25,16.30,4.70,146$ and 130.36 $\mathrm{mg} / 100 \mathrm{~g}$, respectively. These results are similar to Rizk (2004) who revealed that wheat flour (72\% extraction) contained $\mathrm{Fe}, \mathrm{Ca}, \mathrm{Zn}$, and $\mathrm{K}$ valued $1.53,14.13,3.97$ and $136 \mathrm{mg} / 100 \mathrm{~g}$. 
Table 2. Chemical composition of young green barley powder and wheat flour (on dry weight basis)

\begin{tabular}{lcc}
\hline Component (\%) & Young green barley powder & Wheat flour \\
\hline Ether extract & 3.23 & 1.40 \\
Crude protein & 21.15 & 11.69 \\
Ash & 9.37 & 0.60 \\
Crude fiber & 17.53 & 0.65 \\
Total carbohydrate $*$ & 48.72 & 85.66 \\
\hline
\end{tabular}

* Total carbohydrate was calculated by differences.

Table 3. Mineral contents $(\mathrm{mg} / \mathbf{1 0 0 g})$ of young green barley powder and wheat flour $(\mathbf{7 2 \%}$ extraction)

\begin{tabular}{lcccccccc}
\hline Mineral & Fe & Zn & Mn & Mg & Ca & Na & K & P \\
\hline Young green barley powder & 16.35 & 11.40 & 1.45 & 13.27 & 912.56 & 124.53 & 3069.47 & 482.62 \\
Wheat flour (72\% extraction) & 1.70 & 4.2 & 0.80 & 105.25 & 16.30 & 4.70 & 146 & 130.63 \\
\hline
\end{tabular}

\section{Amino Acid Contents of Young Green Barley and Wheat Flour (72\% Extraction)}

Results in Table 4 show that young green barley powder was rich in amino acid content listed arginine, lysine, histidine, phenylalanine, tyrosine, leucine, isoleucine, methionine, valine, alanine, glycine, proline, glutamic acid, serine, threonine, aspartic acid and tryptophan. Mean while, wheat flour (72\% extraction) was poor in essential amino acid contents except histidine compared with young green barley. The present results are in agreement with those of Meng $\boldsymbol{e t}$ al. (2015) who reported that young green barley leaves powder contained arginine, lysine, histidine, phenylalanine, tyrosine, leucine, isoleucine, methionine, valine, alanine, glycine, proline, glutamic acid, serine, threonine, aspartic acid and tryptophan.

Table 5 showed that methionine: glycine ratio was 0.14 compared with casein having 1.72. Also, lysine: arginine ratio of young green barley powder was 1.08 comparative of casein was 1.78. On the other hand leucine: isoleucine ratio of young green barley powder was 1.16 compared with casein bing 1.04. (El-Hadidy, 2014) reported that methionine: glycine ratio or lysine: arginine ratio of casein was high in comparative with tested materials protein, led to hypocholesterolemic ratio in serum of blood. On the other hand, leucine: isoleucine ratio of tested materials was high compared with casein. Also, a significant strong positive correlation with serum cholesterol concentration was noticed.

Results from Table 6 show the first, second and third limiting amino acids of young green barley powder methionine, histidine and Leucine, respectively.

Computed Protein Efficiency Ratio (CPER), Biological Value (BV) of Young Green Barley Powder as Compared With Casein

Results from Table 7 show that the values of computed protein efficiency ratio PER of young green barley powder was 2.8 and Biological value (BV) was 79.36 while in wheat flour $(72 \%$ extraction) PER valued 2.01 and BV was 71.17. On the other hand, the value of PER and BV of casein was 2.50 and 76.23 .

\section{Chemical Composition of Shamy Bread Produced from Wheat Flour $\mathbf{( 7 2 \%}$ Extraction) and Different Levels of Young Green Barley Powder}

Table 8 cleared the chemical composition of shamy bread supplemented with $2,4,6,8$ and 
Table 4. Amino acid compositions of young green barley leaves and wheat flour (72\% extraction) amino acid ratios of young green barley powder as compared with casein

\begin{tabular}{|c|c|c|c|c|}
\hline Type & Amino acids & $\begin{array}{c}\text { Young green } \\
\text { barley powder }\end{array}$ & $\begin{array}{l}\text { Wheat flour } 72 \% \\
\text { (from literature) }\end{array}$ & $\begin{array}{c}\text { FAO/WHO/UNU (1985) } \\
\text { pattern }\end{array}$ \\
\hline \multirow{10}{*}{ 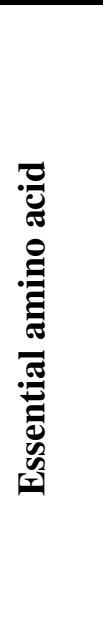 } & Lysine & 8.85 & 2.55 & 5.80 \\
\hline & Isoleucine & 4.54 & 4.00 & 2.80 \\
\hline & Leucine & 5.29 & 4.20 & 6.60 \\
\hline & Phenylalanine + & 8.10 & 5.23 & \multirow{2}{*}{6.30} \\
\hline & Tyrosine & 4.17 & 1.81 & \\
\hline & Histidine & 1.45 & 3.98 & 1.90 \\
\hline & Valine & 8.38 & 4.36 & 3.5 \\
\hline & Threonine & 7.78 & 1.90 & 3.40 \\
\hline & Methionine & 1.12 & 1.20 & 2.20 \\
\hline & Tryptophan & 1.35 & 1.10 & 1.00 \\
\hline \multirow{7}{*}{ 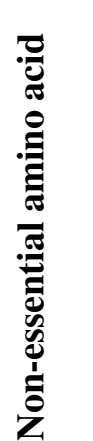 } & Aspartic & 5.95 & 5.41 & \\
\hline & Glutamic & 6.69 & 33.11 & \\
\hline & Serine & 7.63 & 6.70 & \\
\hline & Proline & 3.14 & 12.6 & \\
\hline & Glycine & 8.29 & 3.70 & \\
\hline & Alanine & 9.04 & 3.60 & \\
\hline & Arginine & 8.19 & 2.29 & \\
\hline
\end{tabular}

Table 5. Some amino acid ratios of young green barley powder as compared with casein

\begin{tabular}{lcc}
\hline Ratio & Young green barley powder & Casein \\
\hline Methionine : glycine & 0.14 & 1.72 \\
Lysine : arginine & 1.08 & 1.78 \\
Leucine : isoleucine & 1.16 & 1.04
\end{tabular}

The chemical scores of young green barley powder compared with the required pattern control recommended by FAO/WHO/UNU (1985). 
Table 6. The chemical scores of young green barley powder compared with the required pattern control recommended by FAO/WHO/UNU (1985)

\begin{tabular}{lccc}
\hline Essential amino acid & Recommended pattern & Young green barley powder Amino acid score \\
\hline Lysine & 5.8 & 8.85 & 152.59 \\
Isoleucine & 2.8 & 4.54 & 162.14 \\
Leucine & 6.6 & 5.29 & $80.15^{* * *}$ \\
Phenyle alanine + & 6.3 & 8.10 & 194.76 \\
Tyrosine & 1.9 & 4.17 & $76.32^{* *}$ \\
Histidine & 3.5 & 1.45 & 239.42 \\
Valine & 3.4 & 8.38 & 228.82 \\
Threonine & 2.2 & 7.78 & $50.90^{*}$ \\
Methionine & & 1.12 & \\
\hline
\end{tabular}

Chemical score was calculated as a percentage of the FAO/WHO/UNU (1985) indispensable amino acid.

* First limiting amino acid. ** Second limiting amino acid. ***Third limiting amino acid.

Table 7. Computed protein efficiency ratio (C-PER), biological value (BV) of young green barley powder and wheat flour (72\% extraction) as compared with casein

\begin{tabular}{lccc}
\hline Sample & $\begin{array}{c}\text { Young green barley } \\
\text { powder }\end{array}$ & $\begin{array}{c}\text { Wheat flour 72\% } \\
\text { (extraction) }\end{array}$ & $\begin{array}{c}\text { Casein } \\
\text { reference* }^{*}\end{array}$ \\
\hline${\text { C- }- \text { PER }^{*}}^{*}$ & 2.8 & 2.01 & 2.50 \\
Biological value (B V)** & 79.36 & 71.17 & 76.23 \\
\hline
\end{tabular}

C-PER $=$ computed protein efficiency ratio. $\quad * * \mathrm{BV}=$ Biological value ${ }^{*}$

Table 8. Chemical composition of shamy bread produced from wheat flour ( $72 \%$ extraction) and different levels of young green barley powder

\begin{tabular}{lcccccc}
\hline Component & $\begin{array}{c}\text { Ether } \\
\text { extract } \\
(\boldsymbol{\%})\end{array}$ & $\begin{array}{c}\text { Crude } \\
\text { protein } \\
(\boldsymbol{\%})\end{array}$ & $\begin{array}{c}\text { Ash } \\
(\boldsymbol{\%})\end{array}$ & $\begin{array}{c}\text { Crude fiber } \\
(\boldsymbol{\%})\end{array}$ & $\begin{array}{c}\text { Total } \\
\text { carbohydrate } \\
(\boldsymbol{\%})\end{array}$ & $\begin{array}{c}\text { Energy } \\
\text { value } \\
(\mathbf{C a l} / \mathbf{1 0 0 g})\end{array}$ \\
\hline $\mathbf{1 0 0 \%}$ wheat flour & 1.40 & 11.69 & 0.60 & 0.65 & 85.66 & 411.88 \\
$\mathbf{2 \%}$ Y G B P & 1.44 & 11.88 & 0.78 & 0.78 & 84.91 & 409.94 \\
$\mathbf{4 \%}$ Y G B P & 1.47 & 12.07 & 0.95 & 0.95 & 84.18 & 408.00 \\
$\mathbf{6 \%}$ Y G B P & 1.51 & 12.26 & 1.12 & 1.66 & 83.45 & 406.15 \\
$\mathbf{8 \%}$ Y G B P & 1.55 & 12.45 & 1.30 & 2.00 & 82.70 & 404.22 \\
$\mathbf{1 0 \%}$ Y G B P & 1.58 & 12.64 & 1.48 & 2.34 & 81.96 & 402.24 \\
\hline
\end{tabular}


$10 \%$ of young green barley powder. From the obtained results, it could be noticed that, ether extract, crude protein, ash and crude fiber contents with increased adding young green barley powder, meanwhile, total carbohydrate and energy value decreased as a function of previous treatment compared with control. This may be led to the increment of the aforementioned components in young green barley powder compare with those of wheat flour. Moreover, the young green barley powder improved the nutritive value of produced shamy bread led to increasing of ether extract, crude fiber, crude protein and ash.

\section{Mineral Contents of Shamy Bread} Produced from Wheat Flour $\mathbf{( 7 2 \%}$ Extraction) and Different Levels of Young Green Barley Powder

Results presented in Table 9 show mineral content of shamy bread made from wheat flour (72\% extraction) and different levels of young green barley powder. Minerals comprised of iron, zinc, manganese, calcium, sodium, potassium, phosphors and magnesium were $1.70,4.20,0.80,16.30,4.70,146,130.63$ and $105.25 \mathrm{mg} / 100 \mathrm{~g}$, respectively. All minerals increment of all bread samples made from wheat flour (72\% extraction) containing different levels of young green barley powder were high than control sample, except magnesium which decreased. These minerals were essential for regulation of osmotic pressure and acid base balance (Gabr, 1998). Young green barley powder consist of significant quantities of $\mathrm{Zn}$, $\mathrm{Fe}, \mathrm{Ca}, \mathrm{Mg}, \mathrm{K}$, magnesium $\beta$-carotene, folic acid, chlorophyll, vitamin $\mathrm{C}$, vitamin B12 and pantothenic acid (Lahouar et al., 2015).

\section{Organoleptic Evaluation of Shamy Bread Made from Wheat Flour (72\% Extraction) and Different Levels of Young Green Barley Powder}

Table 10 represented the mean values of sensory evaluation of bread for general appearance, separation of layers, roundness, distribution of crumb, crust colour, taste and odour of shamy bread. The results concerning sensory evaluation of shamy bread made from wheat flour (72\% extraction) and different levels of young green barley powder were illustrate in Table 10 and observed that samples of shamy bread made from $100 \%$ wheat flour $(72 \%$ extraction) were high in acceptability for sample (1) and sample (2) which had a very good grade but, the samples containing 4 and $6 \%$ of young green barley powder have a good grade. Also, samples contain 8 and $10 \%$ of young green barley powder had a satisfactory grade.

\section{Sensory Evaluation of Cantaloupe Juice and Cantaloupe Juice with Barley Drink}

Table 11 show four different cantaloupe juice blends were prepared with different levels of barley grass juice drink (10, 20, 30 and $40 \%)$ which these blends were sensory evaluated and the results are shown in Table 11. The substitution of barley grass juice (10 and 20\%) were more acceptable blends and recorded the highest scores of 44.3 and 42.2 compared with other blends. Increasing the levels of barley grass juice to 30 and $40 \%$ decreased the palatability of produced drinks. The present results are in agreement with those of (Bessar, 2006) who reported that addition barley grass juice to guava juice at different levels of barley grass 10,20 and $30 \%$, respectively were acceptable blends.

Finally, it could be concluded that juice of young green barley cultivars, Giza 129 could be considered as a powerful source of antioxidant (ß-carotene) in addition to many other components substances which important for human nutrition. This juice can be used as a new natural product and to fortify other common juices and drinks.

It can be concluded that consumption of young green barley in shamy bread or cantaloupe juice in different combinations could provide a reasonable daily recommended amount of essential nutrients for maintenance of healthy life and normal body functioning. 
Zagazig J. Agric. Res., Vol. 45 No. (4) 2018

Table 9. Mineral contents of shamy bread produced from wheat flour (72\% extraction) and different levels of young green barley powder

\begin{tabular}{|c|c|c|c|c|c|c|c|c|}
\hline Mineral & $\mathbf{F e}$ & $\overline{Z n}$ & Mn & $\mathrm{Mg}$ & $\mathbf{C a}$ & $\mathbf{N a}$ & $\bar{K}$ & $\overline{\mathbf{P}}$ \\
\hline $100 \%$ wheat flour & 1.70 & 4.20 & 0.80 & 105.25 & 16.30 & 4.70 & 146 & 130.63 \\
\hline $2 \%$ Y G B P & 1.99 & 4.35 & 0.81 & 103.41 & 34.23 & 7.09 & 204.47 & 137.67 \\
\hline $4 \%$ Y G B P & 2.28 & 4.49 & 0.83 & 101.57 & 52.15 & 9.99 & 262.47 & 144.67 \\
\hline $6 \%$ Y G B P & 2.57 & 4.64 & 0.84 & 99.73 & 70.08 & 11.88 & 321.41 & 151.75 \\
\hline $8 \%$ Y G B P & 2.86 & 4.78 & 0.86 & 97.89 & 88.00 & 14.28 & 379.78 & 158.79 \\
\hline $10 \%$ Y G B P & 3.17 & 4.93 & 0.87 & 96.05 & 105.93 & 16.68 & 438.36 & 165.83 \\
\hline
\end{tabular}

Y G B P = Young green barley powder

Table 10. Organoleptic evaluation of shamy bread made from wheat flour (72\% extraction) and different levels of young green barley powder

\begin{tabular}{lccccccccc}
\hline Sample & $\begin{array}{c}\text { Appearance } \\
\mathbf{2 0}\end{array}$ & $\begin{array}{c}\text { Separation } \\
\text { of layer 20 }\end{array}$ & $\begin{array}{c}\text { Roundness Distribution } \\
\mathbf{1 5}\end{array}$ & $\begin{array}{c}\text { Crust } \\
\text { of crumb 15 } \\
\text { colour 10 }\end{array}$ & $\begin{array}{c}\text { Taste } \\
\mathbf{1 0}\end{array}$ & $\begin{array}{c}\text { Odour } \\
\mathbf{1 0}\end{array}$ & $\begin{array}{c}\text { Total } \\
\text { scores 100 }\end{array}$ \\
\hline $\mathbf{1 0 0 \%}$ wheat flour & 19 & 19.3 & 15 & 15 & 9.5 & 9.3 & 10 & 97.1 V.G \\
2\% Y G B P & 18.8 & 18.6 & 14 & 14 & 8.3 & 8.2 & 9 & 90.9 V.G \\
4\% Y G B P & 17.8 & 17.5 & 14 & 13.6 & 8 & 7 & 8.5 & 86.4 G \\
6\% Y G B P & 16.2 & 17.2 & 13.8 & 14 & 7.5 & 6 & 7.5 & 82.22 & $\mathrm{G}$ \\
$\mathbf{8 \%}$ Y G B P & 14 & 16.7 & 14 & 14 & 7.4 & 5.5 & 7.3 & 78.9 & $\mathrm{~S}$ \\
$\mathbf{1 0 \%}$ Y G B P & 13 & 16 & 14 & 14 & 6 & 5 & 6 & 74 & $\mathrm{~S}$ \\
\hline S = Satisfactory. & V.G = very good & $\mathrm{G}=$ good & & Y G B P = young green barley powder &
\end{tabular}

Table 11. Sensory evaluation of cantaloupe juice and cantaloupe with different levels barley drink

\begin{tabular}{lcccccc}
\hline & \multicolumn{5}{c}{ Organoleptic properties } \\
\cline { 2 - 7 } Blend & Taste & Colour & Consistency & Odour & Palatability & Overall \\
& $\mathbf{1 0}$ & $\mathbf{1 0}$ & $\mathbf{1 0}$ & $\mathbf{1 0}$ & $\mathbf{1 0}$ & acceptability 50 \\
\hline Control & 9.8 & 9.8 & 9.8 & 9.7 & 9.7 & 48.8 \\
Barley grass 10\% & 8.9 & 9.1 & 9.0 & 8.8 & 8.5 & 44.3 \\
Barley grass 20\% & 8.3 & 9.0 & 8.5 & 8.2 & 8.2 & 42.2 \\
Barley grass 30\% & 7.9 & 8.2 & 8.4 & 7.8 & 7.6 & 39.8 \\
Barley grass $\mathbf{4 0 \%}$ & 7.6 & 7.9 & 7.8 & 7.2 & 6.9 & 36.4 \\
\hline Cotryyyyyy
\end{tabular}

Control = Cantaloupe $100 \%$ 


\section{REFERENCES}

Alsmeyer, R.H., A.E. Cuningham and M.L. Happich (1974). Equations predict PER from amino acid analysis. Food Technol., 28 (7): $34-40$.

AOAC (2000). Association Official Analytical Chemists. Official methods of analysis $17^{\text {th }}$ Ed., Washington, DC, USA.

Bessar, B.A. (2006). Nutritional and biological studies on green barley leaves as a source of beta carotene. J. Agric. Sci., Mansoura Univ., 31 (5) : 2965-2972.

El-Farra, A.A., A.M. Khorshid, S.M. Mansour and A.N. Elias (1982). Studies on the possibility of supplementation of balady bread with various commercial soy-products. Materials of $1^{\text {st }}$ Egypt. Conf. Bread Res., Cairo, Egypt, 9 -23.

El-Hadidy, G.S. (2014) Chemical, technological and biological studies on mulberry leaves and purslane in Egypt. Ph.D. Thesis, Fac. Agric. Food Technol. Dept., Mansoura Univ., Egypt.

FAO/WHO/UNU (1985). Energy and protein requirements, report of joint $\mathrm{FAO} / \mathrm{WHO} /$ UNU. Expert consultationWorld Health Organization, Technical Report, Series 724, WHO, Geneva.

Farag, S.A., A. El-Shirbeeny and A.E. Nassef (1996). Physicochemical studies for preparing quick-cooking rice by using gamma irradiation. Ann. Agric Sci., Moshtohor, Egypt, 34: 641-652.

Ferreres, F., P.B. Andrade, P. Valentão and A. Gil-Izquierdo (2008). Further knowledge on barley (Hordeum vulgare L.) leaves Oglycosyl-C-glycosyl flavones by liquid chromatography-UV diode-array detection electrospray ionization mass spectrometry, J. Chrom. A., 1182 (1) : 56-64.

Foda, F.F.A. and M.H. Mohamed (2007). Biochemical evaluation of young green barley leaves powder and its application in preparing some fresh juices. Ann. Agric., Sci., Moshtohor, 45 (2):671-684.

Foda, M. (2012). Biochemical studies on antioxidants extracted from young green barley leaves. M.Sc. Thesis, Fac. Agric., Moshtohor, Banha Univ., Egypt.

Gabr, F.A. (1998). Biochemical studies of some wild plants. Ph.D. Thesis, Fac. Agric., Cairo Univ., Egypt.

Gao, T., M. Zhang, Y.B. Han and S.B. Huang (2015). Effect of two drying methods on the quality of barley grass powder. J. Food and Biotechnol., 35 (8) : 822-827.

Gao, T., M. Zhang, Z.X. Fang and Q.F. Zhong (2017). Optimization of microwave-assisted extraction of flavonoids from young leaves, Int. Agrophysics, 31 (1): 45-52.

Gruenwald, J. (2009). Novel botanical ingredients for beverages. Clin Dermatol, 27: 210-216. doi:10.1016/J.Clindermatol.2008.11.003

Gul, S., S. Ahmed and N. Kifli (2014). Multiple pathways are responsible for antiinflammatory and cardiovascular activities of Hordeum vulgare L. J. Translational Med., $12(1): 1-8$.

Hagiwara, Y., H. Hagiwara and H. Ueyama (2001). Physiologically active substances in young green barley leaf extract, Nippon Shokuhin Kagaku Kogaku Kaishi, 48 (10): 12-725.

Ibrahim, O.S. (1992). Effect of some additives on wheat flour dough and bread characteristics. M. Sc. Thesis, Food Sci. and Technol. Dept., Fac. Agric., Cairo Univ., Egypt.

Ikeguchi, M., M. Tsubata and A. Takano (2014). Effects of young barley leaf powder on gastrointestinal functions in rats and its efficacy-related physicochemical properties, Evidence-based Comp. and Alter. Med.

Janda, T., G. Szalai, K. Rios-Gonzales, O. Veisz and E. Pldi (2003). Comparative study of frost tolerance and antioxidant activity in cereals. Pl. Sci., 164 : 301-306.

Jin, H.L., J.P. Mi, H.W. Ryu, H.J. Yuk and S.W. Choi (2016). Elucidation of phenolic antioxidants in barley seedlings (Hordeum vulgare L.) by UPLC-PDA-ESI/MS and screening for their contents at different harvest times, J. Functional Foods, 26 : 667680 . 
Khorshid, A.M., H.A. Nadia, M.A. Nadia and S.F. Jermin (2011). Utilization of flaxseeds in improving bread quality. Egypt. J. Agric. Res., 89 (1): 241-250.

Lahouar, L., S. El-Bok and L. Achour (2015). Therapeutic potential of young green barley leaves in prevention and treatment of chronic diseases: an overview. Ame. J. Chinese Med., 43 (7): 1311-1329.

Lee, S.H., S.S. Jew, P.S. Chang, I.J. Hong, E.S. Hwang, K.S. Kim, K.T. Kim and H.L. Sung (2003). Free radical scavenging effect and antioxidant activities of barley leaves. Food Sci. and Biotechnol., 12: 268-273.

Lindley, M., P. Bets, I. Caanales and F. Borrego (1993). Flavor modifying characteristics of the intense sweetener neohesperidin dihydrochalcone. J. Food Sci., 58 : 592-599.

Markham, K.R. and K.A. Mitchell (2003). The mis-identification of the major antioxidant flavonoids in young barley (Hordeum vulgare) leaves. Zeitschrift für Naturforschung, 58 (2): 53-66.

Meng, F.L., Y.Y. Xu, J.D. Hu, D. He and J.H. Jiang (2017). Optimization of combined drying process by hot-air and microwave for barley seedling powder. J. Food Safety and Quality, 8 (5) : 1651-1658.

Meng, T.X., E. Nakamura and N. Irino (2015). Effects of irradiation with light of different photon densities on the growth of young green barley plants. Agric. Sci., 6 (2): 208216.

Minaiyan, M., A. Ghannadi, A. Movahedian and I. Hakimelahi (2014). Effect of Hordeum vulgare L. (Barley) on blood glucose levels of normal and STZ-induced diabetic rats. Res. in Pharmaceutical Sci., 9 (30) :173-178.

Park, M.J., W.D. Seo and Y.H. Kang (2015). The antioxidant properties of four Korean barley cultivars at different harvest times and profiling of major metabolites. J. Agric. Sci., 7 (10): 94-100.

Paulı'ckova, I., J. Ehrenbergerova, V. Fiedlerova, D. Gabrovska, P. Havlova, M. Holasova, J.
Kopa'c`ek, J. Ouhrabkova, J. Pinkrova, J. Rysova, K. Vaculova and R. Winterova (2007). Evaluation of barley grass as a potential source of some nutritional substances. Czech. J. Food Sci., 25 : 65-72.

Piasecka, A., A. Sawikowska, P. Krajewski and P. Kachlicki (2015). Combined mass spectrometric and chromatographic methods for in-depth analysis of phenolic secondary metabolites in barley leaves. J. Mass Spect., 50 (3): 513-532.

Rizk, E.A.M. (2004). Studies on enrichment of bread. M.Sc. Thesis, Food Technol. Dept., Fac. Agric., Mansoura Univ., Egypt.

Schlüter, T., J. Leide and K. Conrad (2011). Light promotes an increase of cytokinin oxidase/dehydrogenase activity during senescence of barley leaf segments. J. Pl. Physiol., 168 (7): 694-698.

Tausky, H.H. and E. Shorr (1953). Amicrob colorimetric method for the determination of inorganic phosphorus. J. Biol. Chem., 202: 675.

Yang, T., X.Y. Pu, J. Du, P.Y. Xin and Y.W. Zeng (2016). Protein content determination of barley grain and seedling powder. J. Triticeae Crop, 36 (1) : 58-61.

Zeng, Y.W., X.Y. Pu and X.M. Yang (2017). Strategies of functional foods for heart disease prevention in human being in Proceedings from the ICERP-International Conference on Environmental Research and Public Health, pp.108-123,De Gruyter Open Ltd, Warsaw/Berlin.

Zeng, Y.W., L.X. Wang and J. Du (2009). Correlation of mineral elements between milled and brown rice and soils in Yunnan studied by ICP-AES, Spectroscopy and Spectral Anal., 29 (5):1413-1417.

Zhang, H., Y.J. Qiao and W.Y. Qi (2013). Optimization of extraction process of total flavonoids from young barley leaves. Food and Ferment. Indust., 39 (8) : 238-244. 
الاستفادة من بادرات الثعير الأخضر كمصدر غنى بالعناصر الذذائية فى بعض الأغذية

الثحات جمعة الدرينى - جمال سعد الحديدى

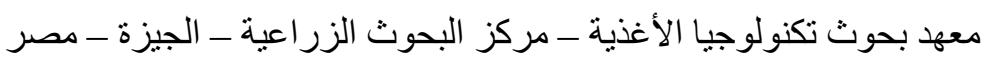

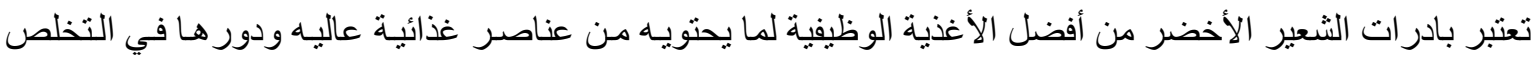

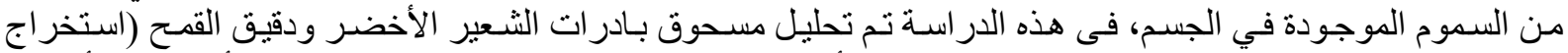

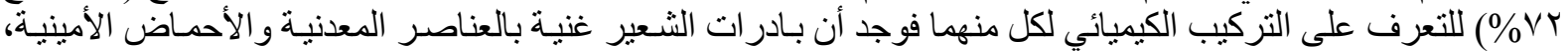

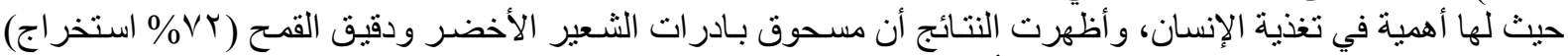

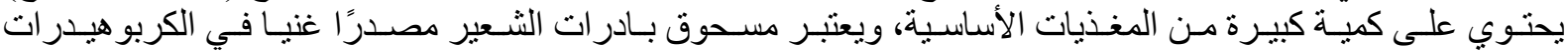

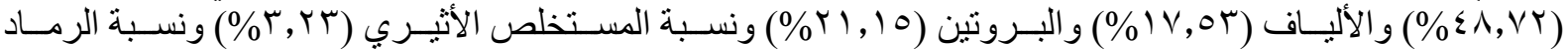

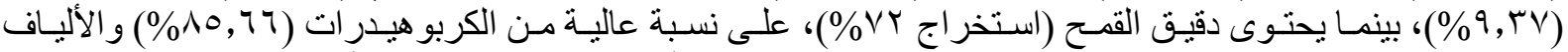

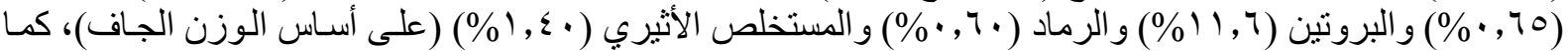

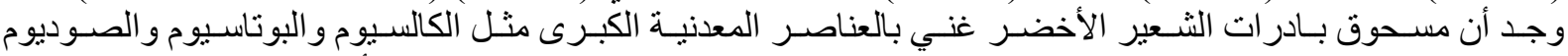

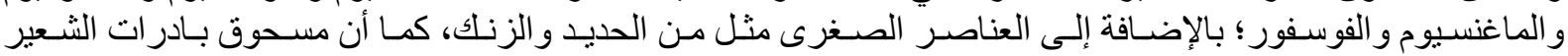

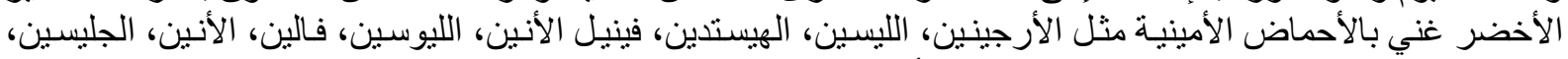

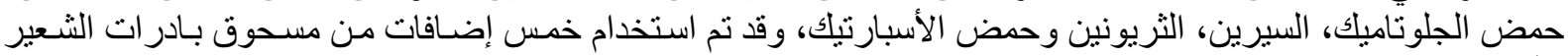

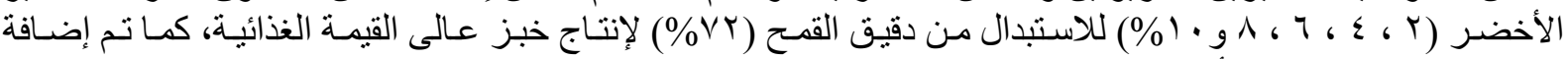

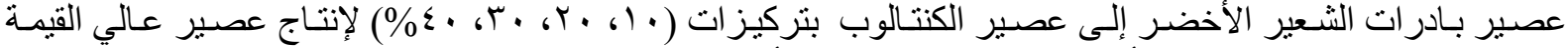

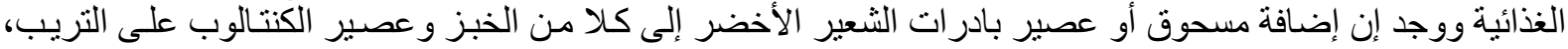

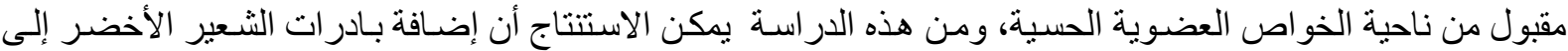
الأغذية يمكن أن تمد الإنسان بالعناصر الغذائية الضرورية للحفاظ على حياة صحية ووظائف الجسم الطبيعية. 